\title{
Kestävän luontomatkailun uhat ja mahdollisuudet Kolin ja Urho Kekkosen kansallispuistoissa
}

Jani Karhu, Itä-Suomen yliopisto, Historia- ja maantieteiden laitos

\section{Abstract}

In the past few decades, sustainable nature tourism has become one of the most growing and debatable fields of the tourism industry. This article focuses on analyzing the possibilities and threats regarding sustainable nature tourism of two Finnish national parks: Koli in North Karelia and Urho Kekkonen National Park in Lapland. The main data of the study consists of the interviews of the park managers and planners and of the survey study of the companies and societies cooperating with the parks. The main findings of the study suggest that the entrepreneurs operating in the national parks have adapted to the sustainability thinking and are developing their businesses in that regard. From the park management's point of view, the concept of sustainable nature tourism and local cooperation by that means has been an effective tool to improve tourism and the positive attitudes towards the parks. Nevertheless, the concept of sustainability is complex, and there are multiple factors setting different expectations for tourism and the parks. This means that reaching a compromise between the park and tourism development and the limits of sustainability is more or less debatable.

Keywords: nature tourism, sustainability, national parks

\section{Johdanto}

Kestävä luontomatkailu, ekoturismi, vastuullinen matkailu ja muut tavalla tai toisella kestävyysajatteluun pohjautuvat matkailun muodot ovat nousseet yhdeksi nopeimmin kasvavista kansainvälisen talouden aloista viime vuosikymmeninä (Buckley, 2004; Edgell \& Swanson, 2013; Fennell, 2004). Matkustamisen ja matkailun motiivit liittyvät yhä enemmän luonnonympäristöihin, historiallisiin kohteisiin, interaktiiviseen toimintaan ja kulttuuriin (Edgell \& Swanson, 2013, s. 147-149; Fletcher, 2014, s. 3-10). Kestävän matkailun ilmiön nimeämisen vaikeus ja sisäisen logiikan ristiriitaisuus ovat olleet osa keskustelua (Blamey, 2001, s. 18-20). Kestävyysajat- 
telun lisääntymisestä huolimatta matkailuteollisuuden erittäin voimakas kokonaiskasvu on tehnyt kestävyydestä yhden turismin suurimmista haasteista (Saarinen, 2018; Utting, 2015, s. 1).

Kansallispuistot ovat ehkä tunnetuin luontomatkailukohde ympäri maailmaa, ja ekologiseen ajatteluun pohjautuvan luontomatkailun kasvun myötä niiden suosio on lisääntynyt entisestään (Balmford, Beresford, Green, Naidoo, Walpole \& Manica, 2009, s. 30-31; Frost \& Hall, 2009, s. 30-44, 300-303). Käsite kestävä luontomatkailu tuli osaksi suomalaisten kansallispuistojen toimintamalleja 2000-luvun alussa (Puhakka \& Saarinen, 2013).

Kestävän matkailun kehittämiseen ja käytäntöön soveltamiseen on liittynyt runsaasti ongelmia (Saarinen, 2018, s. 337; Sharpley, 2009, s. xii-xvi; Utting, 2015, s. 1). Kansainvälisellä tasolla yleisesti määriteltyjen kestävyysperiaatteiden on nähty sopivan huonosti erilaisiin kulttuurisiin ja sosiaalisiin tilanteisiin, eivätkä ne useinkaan tavoita turismin lukemattomia eri kehitysmuotoja (Sharpley, 2009, s. 65). Suomalaisessa viitekehyksessä kehitystyö kestävyysajattelun läpiviemiseksi turismiteollisuuteen ja luontomatkailuun on yhä alkuvaiheessa. Kestävän matkailun ympäristökasvatukseen ja sosiokulttuuriseen puoleen liittyvät teemat eivät ole hahmottuneet kokonaisvaltaisesti paikalliseen toimintakulttuuriin (Lähteenmäki, 2016, s. 150).

Tässä artikkelissa analysoidaan kestävään luontomatkailuun liittyviä uhkia ja mahdollisuuksia historiantutkimuksen näkökulmasta kahdessa suomalaisessa kansallispuistossa, Urho Kekkosen kansallispuistossa Lapissa ja Kolin kansallispuistossa Pohjois-Karjalassa. ${ }^{1}$ Tutkimuskysymys on: mitkä ovat kestävän luontomatkailun mahdollisuudet ja haasteet Kolin ja Urho Kekkosen kansallispuistoissa? Artikkelin aikarajaus perustuu kohteena olevien kansallispuistojen toiminta-aikaan. Urho Kekkosen kansallispuisto (UKK-puisto) aloitti toimintansa vuonna 1983 ja Koli vuonna 1991. Kestävän luontomatkailun käsite tuli osaksi puistojen toimintaa 1990-luvun lopussa, joten analyysin painopiste on 2000-luvussa.

Suomessa kansallispuistot perustetaan lailla valtion omistamille maille. Metsähallituksen Luontopalvelut hoitaa kaikkia Suomen kansallispuistoja. Vuonna 2019 Suomessa on 40 kansallispuistoa. Kansainvälisesti kansallispuistojen perustaminen on pohjautunut kahteen johtavaan ajatukseen: luonnon- ja maisemien suojeluun sekä alueen virkistys- ja matkailukäyttömahdollisuuksiin. Toisaalta näiden teemojen yhdistämiseen liittyvät ristiriidat ovat olleet keskeisiä puistojen hallinnointiin ja toiminnan järjestämiseen liittyviä ongelmia. (Frost \& Hall, 2009, s. 301-303.) Tämän tutkimuksen kohteena olevien kansallispuistojen perustamisvaiheet olivat erilaisten alueiden käyttöön liittyvien ristiriitojen sävyttämiä (Borg, 2013, s. 80; Kortelainen, 1995, s. 69-70; Martikainen, 2016, s. 374). Nämä ristiriidat ovat vaikuttaneet siihen, kuinka matkailua kansallispuistoissa ja niiden lähialueilla on kehitetty ja millaisia haasteita kehittämiseen liittyy.

Artikkeli liittyy tematiikaltaan kansainväliseen keskusteluun kestävyysajattelun kehityksestä suojelualueille kohdistuvassa matkailussa, etenkin pohjoisilla alueilla. Kansainvälises-

1 Artikkeli on osa tutkimushanketta Lively Border. Nature Tourism and History Politics in the Finnish-Russian-Norwegian Border Region (http://www.uef.fi/en/web/greenzoneproject/home), jonka tarkoituksena on etsiä uusia tapoja tarkastella luonnon ja ihmisen välisiä suhteita matkailussa ja paikallisessa muistamisessa. Hankkeen johtaja on historian professori Maria Lähteenmäki Itä-Suomen yliopistosta. Hanketta rahoittaa Koneen Säätiö (nro 64737, 2017-2020). Koli ja UKK-puisto valikoituivat tutkimuskohteiksi hankkeen viitekehyksen ja tutkimustavoitteiden myötä. 
ti kansallispuistot ovat olleet matkailukohteita 1800-luvun loppupuolelta saakka. Suomessa kansallispuistojen suosio matkailukohteina on kasvanut etenkin 2000-luvulla. Moderniin kestävään luontomatkailuun ja suojelualueisiin liittyvä keskustelu on vilkastunut 1990-luvulta alkaen. Tärkeimpiä aiheita ovat olleet matkailun kehitys kansallispuistoissa ja muilla erityisalueilla (Fredman \& Tyrväinen, 2011; Frost \& Hall, 2009; Keiter, 2013) sekä kestävyysajattelun tuominen osaksi suojelualueiden matkailutoimintaa (Fennell \& Dowling, 2003; Keiter, 2013; Plummer \& Fennell, 2009; Puhakka \& Saarinen, 2013). Kestävän matkailun ideaa on kyseenalaistettu jo vuosia, ja matkailun kestävyys on lähtökohtaisesti problemaattista. Kestävään matkailuun yhä vahvemmin liittyvät taloudelliset vaikuttimet ja kasvuodotukset ovat olleet osa keskustelua. (Buckley, 2012; Saarinen, 2018; Swarbrooke, 1999.)

\section{Kestävän luontomatkailun käsite}

Kestävään matkailuun liittyvä keskustelu on ollut vilkasta siitä lähtien, kun ilmiön käsitteellistäminen alkoi. Luontomatkailua painottavista kestävän matkailun käsitteistä kansainvälisesti tunnetuin on ekoturismi. Ekoturismin käsite on kiistelty ja herättänyt keskustelua 1970-luvulta saakka. Ongelmat koskevat varsinkin määrittelyä: mikä on ekologista, mikä on turismia, miten hyötyjä ja haittoja arvioidaan? Usein on pohdittu sitä, missä kulkevat hyödyllisyyden ja kestävyyden sekä toisaalta haitallisten vaikutusten rajat (Edgel \& Swanson, 2013, s. 150). Kansainvälisesti on tehty havaintoja matkailijamäärien laskusta tietyissä luontokohteissa. Tämä voi johtua suuriksi kasvaneista kävijämääristä, jolloin kohteesta tulee vähemmän houkutteleva luontomatkailijoiden silmissä. (Balmford ym., 2009.)

Fletcherin (2014, s. 8) mukaan yksi ensimmäisiä ekoturismin määrittelijöitä oli kansainvälinen ekoturismiyhdistys (TIES). Sen vuonna 1990 laatiman määritelmän mukaan ekoturismi on matkailua, joka huolehtii ympäristöstä ja edistää paikallisten ihmisten hyvinvointia. Blamey (2001, s. 6) kiteytti ekoturismin ominaispiirteet vuosituhannen alussa seuraavasti: luontoon perustuvaa, ympäristötietoista ja kestävästi järjestettyä. Blameyn määritelmä ekoturismista kattaa keskeisimmät kestävyysajatteluun perustuvan turismin piirteet ja tavoitteet, jotka löytyvät muun muassa Maailman matkailujärjestön (UNWTO) kestävän matkailun määritelmästä: "Matkailua, joka huomioi taloudelliset, sosiaaliset ja ekologiset vaikutukset niin matkailijan, toimialan, ympäristön kuin paikallisyhteisöjen näkökulmasta." (Sustainable development of tourism.)

Kestävän luontomatkailun periaatteet -kokonaisuus laadittiin Metsähallituksessa vuonna 2004 (Heinonen, 2007, s. 149). Metsähallituksen periaatteet kestävälle matkailulle perustuivat kansainväliselle ajatusmallille ja rakentuvat seuraavien teemojen alle: kohteiden suojelu ja arvojen säilyminen, ympäristökuormituksen minimoiminen, paikallisuuden vahvistaminen, talouden edistäminen sekä hyvinvoinnin ja yhteisen viestinnän edistäminen. (Metsähallitus, 2018b.) Käytännössä Metsähallituksen kestävän luontomatkailun periaatteet ovat paikallisen tason sovellus kansainvälisistä ekoturismin periaatteista.

Metsähallituksen käyttämä kestävän luontomatkailun käsite on artikkelin keskeisin viitekehyksellinen työkalu. Tämä on perusteltua, koska tällä käsitteellä on ohjattu kansallispuisto- 
jen suunnittelua ja käyttöä 2000-luvun alkupuolelta saakka (Puhakka, 2007, s. 171-172). Historiantutkimukselle tyypilliseen tapaan viitekehyksellistä työkalua käytetään empirialähtöisesti aineiston analyysissä ja kontekstin rakentamisessa. Metsähallituksen periaatteiden mukaan kansallispuistoilla ja muilla suojelualueilla on suuri merkitys matkailun vetovoimatekijöinä ja suojelualueiden hyödyntäminen matkailussa on mahdollista, kun se sovitetaan yhteistyössä yhteen suojelutavoitteiden kanssa. Metsähallituksen Luontopalveluilla ja UNESCOn maailmanperintökohteilla Suomessa on yhteiset kestävän matkailun periaatteet, jotka Metsähallitus ilmoittaa ottavansa huomioon kaikessa organisaation toiminnassa. (Metsähallitus, 2018b.)

\section{Tutkimusalue ja luontomatkailu}

UKK-puisto on perustettu vuonna 1983 ja Kolin kansallispuisto vuonna 1991. Molempien puistojen perustamisesta käytiin pitkällinen keskustelu. Puistojen perustamista vastustettiin etenkin paikallisesti, sillä maa- ja metsätalouden työpaikkojen uskottiin katoavan ja puistojen mukanaan tuomia rajoituksia pelättiin. UKK-puistoa ehdotettiin ensimmäisen kerran Itäkairan puisto -nimellä vuonna 1961. Ehdotuksia Kolin kansallispuistosta esiintyi 1920-, 1950- ja 1970-luvuilla (Kortelainen, 1995, s. 66; Partanen, 1992, s. 44.) Ensimmäiset kansallispuistohankkeet kaatuivat muun muassa paikallisten ihmisten vastustukseen (Borg, 2013, s. 80; Martikainen, 2016, s. 373).

Molempien puistojen alueella matkailu oli tärkeä osa kulttuuria jo pitkään ennen kansallispuistojen perustamista. UKK-puiston alueella retkeilyn suosio alkoi kasvaa 1950-luvulla, ja Kolilla matkailua ryhdyttiin kehittämään jo 1800-luvun lopulla. Laskettelu alkoi Kolilla 1930-luvulla. (Partanen, 1992; Saarelainen, 2016.) Kansallispuistojen ja matkailun välisessä suhteessa tapahtui merkittävä käänne vuosituhannen vaihteessa. Kestävästä luontomatkailusta tuli keskeisin kansallispuistojen hoitoa ja käyttöä ohjaava tekijä Suomessa (Puhakka, 2007).

Keväällä 2000 ympäristöministeriössä ryhdyttiin valmistelemaan ohjelmaa luonnon virkistyskäytön ja luontomatkailun kehittämiseksi: luontomatkailu haluttiin osaksi työllisyyden parantamista. Ohjelmalla pyrittiin kaksinkertaistamaan luontomatkailun työpaikat vuoteen 2010 mennessä ja tekemään luontomatkailusta aluetaloudellisesti merkittävää. (Ympäristöministeriö, 2002.) Kyse oli laajemmasta kansainvälisestä luontomatkailun merkitysten muutoksesta ja muuttamisesta, joka Suomessa tapahtui valtiojohtoisesti. (Frost \& Hall, 2009, s. 309; Mose, 2007, s. XV; Puhakka \& Saarinen, 2013.) Aiemmin matkailun merkitystä metsäluonnon käyttömuotona pidettiin Suomessa vähäisenä. Luontoon perustuvan matkailun uskottiin jopa jarruttavan tai estävän taloudellista kehitystä, koska matkailu miellettiin metsätalouden kilpailijaksi. (Puhakka, 2007, s. 130.)

Luontomatkailun kehittämisen tultua osaksi puistojen toimintaa matkailijamäärät ovat kasvaneet voimakkaasti. Vuodesta 2003 vuoteen 2018 vierailijamäärien kasvu on UKK-puistossa ollut noin 112 \% ja Kolilla noin 90 \%. (Metsähallitus, 2019; Puhakka, 2007, s. 137-139.) Käyntimäärien tarkka laskeminen ei kuitenkaan ole yksinkertaista, ja etenkin UKK-puistossa Saariselän matkailukeskuksesta saapuvien päiväretkeilijöiden tilastointi on ollut haastavaa (Metsähallitus, 2001, s. 44). Todennäköistä on, että osa päiväkävijöistä jää edelleen tilastoimatta. 
Kansallispuiston status ei automaattisesti tarkoita alueen kehittymistä merkittäväksi matkailukohteeksi. Suomessa suosituimpia ovat pohjoisen Pallas-Yllästunturin kansallispuisto ja UKK-puisto sekä pääkaupunkiseudun Nuuksion kansallispuisto. Yli 200000 kävijän puistoja Suomen 40 kansallispuistosta oli vuonna 2018 kolme, kun taas alle 20000 vuosittaisen vierailijan puistoja oli 14. Vuonna 2018 Kolilla tilastoitiin 190900 vierailijaa ja UKK-puistossa 340000 vierailijaa. (Metsähallitus, 2019.)

Kävijätutkimusten mukaan kansallispuistoihin saavutaan ennen kaikkea luonnossa liikkumisen ja maisemien ihailun motivoimana (Koskeli-Rantamaa, 2016; Kuusisto, 2018). Kolilla ja UKK-puistossa tärkeimmät syyt vierailuun ovat olleet maisemat, luonnon kokeminen ja rentoutuminen (Koskeli-Rantamaa, 2016, s. 37; Kuusisto, 2018, s. 38). Matkailijamääriltään huomattavasti pienemmissä Salamajärven ja Pyhä-Häkin kansallispuistoissa vierailumotiivit ja tärkeimmät harrasteet ovat hyvin pitkälle samoja kuin kymmenkertaisten kävijämäärien Kolilla ja UKK-puistossa (Ala-Fossi \& Mikkola, 2017, s. 19, 33; Mansikkaviita, 2012, s. 19, 33). Eniten kävijämääriään 2000-luvulla ovat kasvattaneet matkailukeskusten välittömässä läheisyydessä olevat kansallispuistot, kuten Koli, Pallas-Ylläs ja UKK-puisto (Metsähallitus, 2017).

\section{Aineistot ja menetelmät}

Artikkeli perustuu Kolin ja UKK-puiston puistonjohtajille ja suunnittelijoille tehtyihin teemahaastatteluihin sekä puistojen kanssa yhteistyösopimuksen tehneille yrityksille osoitettuun kyselyyn. Haastattelujen ja kyselyaineiston yhdistelmällä on pyritty syventämään tutkimuskohteesta saatavaa tietoa. Kolin kansallispuistossa käytettiin myös osallistuvan havainnoinnin menetelmää. Haastattelujen ja kyselyn lisäksi artikkelissa on hyödynnetty kansallispuistojen suunnitteluraportteja ja yritystutkimuksia.

\section{Haastatteluaineisto}

Haastattelut tehtiin kesäkuun 2017 ja helmikuun 2019 välillä. Haastateltavat valittiin heidän työhistoriansa perusteella: kaikki ovat työskennelleet tutkituissa kansallispuistoissa puistonjohtajina tai suunnittelijoina ja olleet mukana kestävän luontomatkailun kehittämisessä. UKK-puistosta haastateltiin viittä ja Kolilta kuutta henkilöä. Haastattelut tehtiin joko sähköpostitse ( $8 \mathrm{kpl})$, puhelimitse ( $3 \mathrm{kpl}$ ) tai kasvotusten ( $3 \mathrm{kpl})$. Osaa henkilöistä haastateltiin useamman kerran. Tavoitteena oli luoda haastateltujen omakohtaisten kokemusten ja asiantuntemuksen kautta kuva kestävän luontomatkailun kehittämiseen ja käytäntöihin liittyvistä kehityslinjoista sekä mahdollisuuksista ja haasteista tutkimuksen kohteena olleissa kansallispuistoissa.

Haastattelut analysoitiin laadullisen sisällönanalyysin keinoin. Sisällönanalyysissä aineistoa tarkastellaan eritellen, yhtäläisyyksiä ja eroja etsien ja tiivistäen. Tutkittavasta ilmiöstä pyritään muodostamaan tiivistetty kuvaus, joka kytkee tulokset ilmiön laajempaan kontekstiin ja aihetta koskeviin muihin tutkimustuloksiin. (Tuomi \& Sarajärvi, 2002, s. 105.) Koska osa haastateltavista toivoi anonymiteettiä, haastattelutiedonannot numeroitiin ja päivättiin ja muut tunnistetiedot jätettiin pois. 


\section{Kyselyaineisto}

Molemmista kansallispuistoista saatiin sähköpostiosoitelista yrityksistä, jotka ovat tehneet yhteistyösopimuksen puiston kanssa. Yhteistyösopimus tarkoittaa, että yritys sitoutuu kestävän luontomatkailun periaatteiden noudattamiseen (Metsähallitus, 2016). Kyselyn laajuudesta ja kysymysten tarkoituksenmukaisuudesta keskusteltiin molempien puistojen henkilökunnan kanssa. Kolilla pyrittiin välttämään liikaa päällekkäisyyttä Metsähallituksen äskettäin tekemän yrityskyselyn kanssa.

Kyselyn tarkoituksena oli analysoida yhteistyöyritysten suhtautumista kestävään luontomatkailuun sekä kestävän matkailun merkitystä yritysten toiminnassa - ja tätä kautta arvioida kestävän luontomatkailun uhkia ja mahdollisuuksia. Lomakkeessa oli kahdeksan kysymystä, jotka perustuivat Metsähallituksen Kolilla käyttämään yrityskyselyyn. Kysymyksissä kartoitettiin kestävän luontomatkailun periaatteiden tunnettuutta, suhtautumista kestävyysajatteluun ja siihen liittyviin käytänteisiin, ekoturismin tai muiden kestävän matkailun muotojen roolia yrityksen toiminnassa nyt ja tulevaisuudessa sekä vastaajan näkemystä kohdealueen kestävään luontomatkailuun liittyvistä hyödyntämättömistä mahdollisuuksista. Lisäksi kysyttiin yrityksen päätoimiala ja toiminta-aika.

Yhteistyöyrityksiä oli tutkituissa puistossa yhteensä 67. Kolilla yhteistyösopimuksia on tehty huomattavasti enemmän kuin UKK-puistossa: Kolin yhteystietolistassa oli 52 ja UKK-puiston listassa 15 yhteystietoa. Tämä johtuu osaksi siitä, että Kolilla yhteistyösopimukset tehdään biosfäärialueen mukaan, mikä tarkoittaa huomattavasti laajempaa aluetta kuin vain Kolin kansallispuistoa. Samaan Pohjois-Karjalan biosfäärialueeseen kuuluu esimerkiksi Ilomantsin alue. Biosfäärialueet ovat kestävän kehityksen mallialueita, jotka kuuluvat UNESCOn "Ihminen ja biosfääri” -ohjelmaan. (Pohjois-Karjalan biosfäärialue).

Kyselytutkimus tehtiin loka-marraskuussa 2018. Kysely lähetettiin digitaalisena linkkinä yritysten sähköpostiosoitteisiin. Vastauspyyntö uusittiin kolme viikkoa ensimmäisen pyynnön jälkeen. Vastauksia saatiin kaikkiaan 25 kappaletta: Kolilta 21 (40\%) ja UKK-puistosta 4 (26\%). Kolin aineistossa oli havaittavissa, että yritykset, joilla ei ollut kansallispuistoon liittyvää toimintaa, olivat jättäneet vastaamatta. Tämä lisää Kolia koskevan kyselyaineiston edustavuutta.

Vastauksia tarkastellaan suorien jakaumien ja ristiintaulukoiden pohjalta. Niiden avulla voidaan nostaa esille tutkimustehtävän kannalta olennaiset huomiot sekä vertailla puistoja keskenään. Avoimien kysymysten vastaukset analysoitiin sisällönanalyysillä.

\section{Havainnointiaineisto}

Kolin kansallispuistossa hyödynnettiin myös osallistuvan havainnoinnin menetelmää. Kirjoittaja osallistui kahteen Kolin alueen kehittämistä ja suunnittelua käsitelleeseen keskustelutilaisuuteen: "Koli Treffeihin" 20.12.2017 ja Kolin matkailun kehittämistilaisuuteen 20.1.2018. Tilaisuudet olivat Kolin keskeisten toimijoiden, Lieksan ja Juuan kuntien, organisoimia. Koli Treffit kokosivat yhteen kaikki Kolin tulevaisuudesta kiinnostuneet toimijat, ja sen viitekehyksenä toimi Koli Isokuva 2050 -suunnitelma. Kirjoittaja osallistui tapahtumiin keskustelua tarkkaillen sekä kuntien virkamiesten ja paikallisten yrittäjien kanssa keskustellen. Osallistuva havainnointi auttoi tutkittavan ilmiön ja eri aineistomuotojen asettamista paikalliseen kontekstiinsa. 
Havainnoinnin muistiinpanot analysoitiin sisällönanalyysillä. Havainnointiaineiston analyysin tavoitteena oli tuoda paikallistason luontomatkailukeskustelu yleiselle tasolle.

\section{Asiakirja-aineisto}

Edellä esiteltyjen empiiristen aineistojen lisäksi koottiin puistojen kehittämiseen ja suunnitteluun liittyvä aineisto. Se koostuu kansallispuistojen käytön ja suunnittelun ohjeistusraporteista, Metsähallituksen, Metsäntutkimuslaitoksen ja ympäristöministeriön suunnitteluraporteista sekä kansallispuistojen yritys- ja käyttäjäkyselyistä. Empiiristen aineistojen sekä puistojen toiminta- ja suunnitteluraporttien avulla oli mahdollista vertailla kestävyysajatteluun ja -käytäntöihin liittyviä kehityslinjoja kahden eri puiston välillä sekä muodostaa kokonaiskuvaa ilmiöstä. Asiakirja-aineisto täydensi muuta tutkimusaineistoa ja helpotti paikallisen toiminnan ja tavoitteiden ymmärtämistä ja yhdistämistä yleisemmän tason ilmiöihin. Asiakirja-aineisto analysoitiin käyttäen samoja sisällönanalyysin periaatteita kuin haastatteluaineiston analyysissä.

\section{Sisällönanalyysi}

Sisällönanalyysi eteni seuraavasti. Aineistosta erotettiin ensin teemalliset kokonaisuudet, jotka perustuivat haastattelurunkoon. Nämä teemalliset kokonaisuudet olivat: kestävyysajattelun lähtökohdat tutkimusalueella, matkailun ohjaaminen ja käsitteet tutkimusalueella, paikalliset toimijat ja matkailu, tutkimusalue ja asiakkaat, keskeiset mahdollisuudet ja haasteet. Aineistoa eritellen, yhtäläisyyksiä ja eroja etsien ja tiivistäen, teemoista nousivat esille seuraavat keskeiset osa-alueet: paikalliset ristiriidat, yhteistyön merkitys, kestävyysajattelun ja toimintamallien omaksuminen ja käyttöönotto, kestävyyden arvioinnin ja painottamisen haasteet sekä kestävän luontomatkailun hyödyntämättömät mahdollisuudet. Osa-alueita analysoidaan seuraavissa alaluvuissa artikkelin ongelmanasettelun mukaisesti.

\section{Kestävän luontomatkailun mahdollisuudet ja haasteet}

Tässä alaluvussa tarkastellaan kestävän luontomatkailun mahdollisuuksia ja haasteita puisto-organisaation toimijoiden näkökulmasta eli etupäässä haastatteluaineiston, osittain myös havainnointiaineiston, pohjalta.

Kaikkein tärkeimpänä edellytyksenä kestävän luontomatkailun kehittämiselle ja mahdollisuuksien hyödyntämiselle toimijat pitivät puistojen sekä paikallisten yrittäjien ja yhteisöjen välisiä toimivia ja kattavia yhteistyöverkostoja. Yhteistyön merkitys onkin todettu useaan kertaan ensiarvoisen tärkeäksi luonnonsuojelualueiden ja matkailutuotteiden kehittämisessä. (McCool, 2009; Puhakka, Sarkki, Cottrell \& Siikamäki, 2009, s. 544-545.) Yhteistyön korostaminen palautuu myös puistojen riitaiseen historiaan ja kamppailuun siitä, mihin alueita käytetään ja kenen ääntä kuullaan.

Haastateltavien mukaan kasvaneet matkailijamäärät ovat tuoneet elinkeinomahdollisuuksia myös paikallisisille asukkaille. Puistot ovat pyrkineet aktiivisesti kehittämään toimivaa yhteistyötä paikallisten kanssa. Tämän ansiosta luonnonsuojelu ja alueiden käytön rajoitteet on helpompi hyväksyä. Kestävän luontomatkailun käsite ja käytänteet ovat toimineet tärkeänä 
työkaluna luontomatkailun ja luonnonsuojelun mahdollisuuksien edistämisessä ja yhteistyön rakentamisessa.

\section{Kolin kansallispuistossa}

Haastateltujen puistotoimijoiden mukaan yhteistyötä on Kolilla pyritty rakentamaan kansallispuiston alkuvaiheista saakka, mutta etenkin vuonna 1997 aloitettu kehittämishanke oli askel systemaattisempaan toimintaan. Puistolle hankittiin kansainvälinen Europarc-sertifikaatti osoituksena kestävästä toiminnasta ja suunnittelusta. Sertifikaatti perustui kahdeksanportaiseen kestävän matkailun strategiaan. Tärkeimmäksi kehittämisen osa-alueeksi Kolilla muodostui paikallisten yhteistyöverkostojen ja ympäristön kannalta kestävämpien toimintamallien luominen. Tavoitteena oli lisätä suojelualueelle suuntautuvan matkailun kestävyyttä ja huomioida paremmin alueen erityispiirteet avoimen ja integroivan suunnitteluprosessin avulla (Manner, 2007).

Kolilla tunnistettiin kestävyysajattelun ja ekoturismin kansainvälinen kasvu, ja kansallispuisto haluttiin liittää osaksi tätä ilmiötä. Silloinen Kolin hoito- ja käyttösuunnitelma (Lovén, 2005) pyrittiin laatimaan demokraattisesti, yhteistyössä alueen toimijoiden kanssa. Se ei kuitenkaan ollut helppoa, sillä kehityshankkeen alkaessa Kolin alueen sosiaalinen valmius yhteistyöhön oli puistonjohdon näkökulmasta olematonta. Kyse oli enemmänkin avoimesta taistelusta erilaisten käyttötavoitteiden, paikallisen taloudellisia arvoja korostavan näkemyksen ja ylipaikallisen kansallisia maisema- ja luontoarvoja kannattavan näkemyksen välillä. Toinen osapuoli kannatti laskettelurinteiden ja hotellin suurisuuntaista laajentamista, toinen taas pyrki pitämään maiseman luonnontilaisena ja alueiden käytön rajattuna, jotta herkät luontokohteet ja muut suojeluarvot eivät vaarantuisi.

Tärkein keino, jolla tilannetta pyrittiin ratkaisemaan, oli haastateltavien mukaan verkostoituminen ja paikallisten kannustaminen osallistumiseen. Tämä johti muun muassa Kolin kotiseutuyhdistyksen ja kulttuuriyhdistyksen perustamiseen. Vähitellen ristiriitoja on saatu ratkottua, ja nykyään kansallispuiston arvo myös taloudellisten mahdollisuuksien luojana tunnustetaan aikaisempaa laajemmin.Yksi haastatelluista kuvasi yhteistyön rakentamista seuraavasti:

Mä yritin siinäkin [ristiriitojen lieventämisessä] löytää sellaisia toimintamalleja, joita kutsutaan tänä päivänä verkottumiseksi. Elikkä silloinhan ei ollut mitään yhdistystoimintaa, urheiluseura oli eikä muuta. Että sitten kannustin näitä paikallisia, kun heillä oli omia ajatuksia kotiseututyössä, nïn mä innostin niitä perustamaan kotiseutuyhdistyksen ja ne teki sen--. (Haastattelu 8)

Kolin luontomatkailun mahdollisuudet perustuvat haastateltavien mukaan ennen kaikkea laadukkaaseen kansainvälisesti sertifioituun tuotteeseen. Markkinoitaessa Kolia kansainvälisesti voidaan luottaa siihen, että kestävyys todella huomioidaan. Luonnossa liikkumisen ja luontokokemusten arvostamisen kasvava trendi asettaa kansallispuistoille paljon odotuksia, mutta se on ennen kaikkea mahdollisuus, johon laadukkaalla matkailutuotteella voidaan vastata.

Puistohallinnon näkökulmasta Koli luontokohteena (esimerkiksi polkuverkostonsa puolesta) pystyy vastaanottamaan huomattavasti nykyistä suurempia matkailijamääriä ilman, että kestävyydelle asetetut rajat vaarantuisivat. Kasvun esteeksi voivat sen sijaan muodostua sosiaa- 
lisen kestävyyden rajat paikalliskulttuurin näkökulmasta. Yksi Kolin haastatelluista kuvasi ongelmaa seuraavasti:

- - inhimillinen resurssi on se ongelma, nämä [kasvavat kävijämäärät] aiheuttaa sellaista painetta ihmisissä, että sitä on vaikea kestää. Nämä ihmiset erämaassa, niin ei ne kestä viikkoa kauempaa hymyillä matkailijoille, että se on se suurin haaste. Silloin kun asiakkaita käy, esimerkiksi juhannuksena, niin täällähän ei ollut muuta kuin Sale auki. (Haastattelu 8)

Sosiaalisen kestävyyden ohella kasvun haasteet liittyvät alueen muuhun infrastruktuuriin, kuten liikenneyhteyksiin, paikoitustiloihin ja matkailijavirtojen alueelliseen kohdentumiseen. Suuri haaste on saada matkailijat käyttämään puistoaluetta ja polkuverkostoja kokonaisvaltaisemmin. Nykyisin vierailut ovat suurimmaksi osaksi pikaisia kansallismaiseman ihailuja hotellin ja kansallispuiston luontokeskus Ukon ympäristössä, minkä takia alue ruuhkautuu helposti ja paikoitustiloista on pulaa. Koska henkilöauton korvaavia kulkuyhteyksiä ei ole järjestetty, sesonkiaikaan alueelle tuleva voi joutua jättämään vierailunsa kokonaan väliin.

Edellä todettu tilanne vaikuttaa kielteisesti koko alueen matkailukehittämiseen. Helppoja ratkaisuja ei ole, koska hotelli ja luontokeskus paikoitusalueineen sijaitsevat kansallispuiston sisällä. Merkittävät laajentamistoimet olisivat kauaskantoinen päänavaus rakentamiselle kansallispuiston alueella. Paikoitustilakysymys onkin saattanut vastakkaisia näkemyksiä Kolin alueen kehittämisestä jo pitkään esittäneet luonnonsuojeluyhdistyksen ja paikallisen yrittäjäväen uuteen vastakkainasetteluun. (Lehtinen \& Kiiskinen, 2019; Virolainen, 2019.)

Matkailun kestävyys- ja investointikysymykset ovat olleet Kolilla vahvasti esillä, koska alueelle laaditussa Koli iso kuva 2050 -suunnitelmassa tavoitellaan nykytilanteeseen verrattuna moninkertaisia vuosittaisia matkailijamääriä ja merkittäviä alueellisia investointeja kansallispuiston lähialueille (ks. Kolin kehittämisen iso kuva). Suunnitelmaa käsiteltiin Koli Treffeillä joulukuussa 2017. Tilaisuuden keskustelujen perusteella suunnitelma ei ole ongelmaton. Mikäli kunnat ja yksityiset yritykset investoivat voimakkaasti matkailun kehittämiseen ja kävijämäärien kasvattamiseen, tilanne voi muodostua kansallispuiston näkökulmasta kestämättömäksi. Merkittävin yksittäinen suunnitelma on kansallispuiston välittömään läheisyyteen sijoittuva noin 100 miljoonan euron - tuhat vuodepaikkaa sisältävä - luontomatkailukeskus. Tulevaisuuskuvan toteuttaminen vaatisi kansallispuiston näkökulmasta erityistä viisautta, jotta vaikutukset eivät muodostuisi negatiivisiksi.

\section{Urho Kekkosen kansallispuistossa}

UKK-puistossa otettiin yleisesti määritellyt kestävän luontomatkailun periaatteet käyttöön heti niiden laatimisen jälkeen 2000-luvun alussa. Puistonjohtajan vastuulla oli lisätä matkailua kestävällä tavalla. Prosessissa korostui paikallinen yhteistyö ja ympäristöministeriön asettamiin matkailutavoitteisiin vastaaminen.

Haastateltujen puistotoimijoiden mukaan sujuvien yhteistyömuotojen löytäminen paikallisten intressiryhmien kanssa on ollut puiston ja matkailun kehittämisen kannalta välttämätöntä. Toimivaksi yhteistyömuodoksi rakentui neuvottelukuntatoiminta. Neuvottelukunta on puiston toimintaa ohjaava elin, johon on koottu kaikki alueen keskeiset toimijat. Neuvottelukunnan anti puiston kehittämiselle on liittynyt sen rooliin konflikteja ennaltaehkäisevänä keskustelufoorumina. Näin siitä ei ole muodostunut rasitetta puistohallinnolle vaan päinvastoin 
voimavara. Muun muassa keskeiset luontomatkailu- ja kalastuksenhoitosuunnitelmat toteutettiin neuvottelukunnan hyväksymänä. Toimivan yhteistyön ansiosta aikaisempi kielteinen suhtautuminen kansallispuistoon ja sen mukanaan tuomiin rajoituksiin on lieventynyt merkittävästi. Kasvaneet matkailun taloudelliset hyödyt myös paikallisille ovat edesauttaneet yhteisymmärryksen luomista. Yksi haastatelluista kuvasi yhteistyön haasteita seuraavasti:

Kestävyysajattelussa oli suurta vaihtelua. Toiset sanoivat jo ensi tapaamisella noudattavansa kaikkia määräyksiä ja ohjeita [jotka oli asetettu viime kädessä kestävän matkailun toiminnan turvaamiseksi ja luonnon suojelemiseksi], kun taas toiset eivät niistä piitanneet tai suhtautuivat vihamielisesti Metsähallitukseen ja kansallispuiston toimintaan ja siellä työskenteleviin. Vuosien varrella tässä tapahtui vähittäisesti suuri muutos. (Haastattelu 4)

Useiden haastateltavien mukaan keskeisiä haasteita UKK-puistossa ovat kasvavan luontomatkailun erilaisten vaikutusten ennakointi sekä erilaisten käyttäjäryhmien tarpeiden huomioiminen. Puiston välittömässä läheisyydessä sijaitsevan Saariselän matkailukeskuksen mukanaan tuoma matkailijapotentiaali on huomattava, mutta haasteena on säilyttää puiston erämainen ominaisluonne vahvana. Paikallisten poronhoitajien, omatoimisten rinkkaretkeilijöiden, lyhyellä visiitillä olevien päiväretkeilijöiden, suurempien opastettujen turistiryhmien ja esimerkiksi pyöräilijöiden kohtaamisista on tullut kriittistä palautetta: kaikki eivät tahdo mahtua samoille reiteille, vaikka puisto onkin laaja. UKK-puisto mielletään maiseman laadun ja ekologisen kestävyyden takaajaksi, mutta koetun sosiaalisen kestävyyden rajat ovat vaellusretkeilijöillä alhaisemmat kuin päiväretkeilijöillä. Vähäinenkin määrä muita retkeilijöitä tai käyttäjäryhmiä tekee maisemasta vaeltajien silmissä ruuhkaisen. Vastaavasti paikalliset asukkaat saattavat pyrkiä välttämään matkailijoiden ja retkeilijöiden kohtaamista liikkumalla eri alueilla ja eri aikoina. Sosiaalisen kestävyyden rajat eri matkailijaryhmien, paikallisten asukkaiden ja elinkeinonharjoittajien välillä voivat näin tulla vastaan aikaisemmin kuin luonnonympäristön kestävyyden rajat.

Puistotoimijoiden mukaan UKK-puiston luontomatkailun mahdollisuudet liittyvät kattavalla yhteistyöllä rakennettuun kansainväliseen tuotteeseen. Alue on laaja, ja se tarjoaa mahdollisuuksia eri tyyppisille aktiviteeteille. Sijainti Saariselän matkailukeskuksen kupeessa lisää mahdollisuuksia huomattavasti. Ilman paikallisen tason toimivaa yhteistyötä tulevaisuutta ei kuitenkaan ole. Etenkin toimivat suhteet poronhoitoon on koettu elintärkeiksi. Kestävän matkailun käsite tunnetaan aikaisempaa paremmin ja sen tarve on tunnustettu, vaikka toimivien käytäntöjen löytäminen onkin vienyt vuosia. Yritysten ja puiston väliset yhteistyösopimukset edistävät kestävyysajattelun läpiviemistä ja tukevat näin kestävän luontomatkailun kehitystä.

Suomessa matkailun tulo elimelliseksi osaksi kansallispuistojen toimintaa ja aluetaloudellisia tavoitteita on vienyt luonnonsuojelua markkinavetoisempaan ja välineellisempään suuntaan (Puhakka \& Saarinen, 2013). Tämä kehityssuunta tuli esille UKK-puiston haastatteluissa. Kansallispuiston aluetaloudelliset hyödyt ovat vahvat, ja matkailun edistämisellä on perusteltu rajoitusten lieventämistä ja suojelunäkökulmista joustamista. Myös kansainvälinen tutkimus on osoittanut luontomatkailun taloudellisen potentiaalin (Das \& Hussain, 2016; Mayer, 2014).

Tavoitteet taloudellisesta, ekologisesta ja sosiaalisesta kestävyydestä eivät välttämättä ole yhdenmukaisia, vaan toisen etu voi olla toisen haitta (Puhakka ym., 2009, s. 536-540; Zeppel, 
2015, s. 195). UKK-puistossa, kuten Kolillakin, tämä näkyy ristiriitana eri käyttäjä- ja intressiryhmien välillä sekä puisto-organisaation huolena sosiaalisen kestävyyden tasapainosta.

Haastateltavat eivät esittäneet haasteina matkailuun liittyviä globaalin tason kestävyyskysymyksiä, vaan heidän näkökulmansa haasteisiin oli hyvin paikallinen. Mahdollisuuksien kohdalla sen sijaan puhuttiin myös kansainvälisyydestä ja ulkomaalaisten turistien lisääntymisestä.

Eri käyttäjäryhmien välisten intressien yhteensovittaminen ja kasvavien kävijämäärien mahdolliset kielteiset vaikutukset tulivat tavalla tai toisella esiin haasteena ja huolena kaikissa UKK-puiston haastatteluissa. Lisäksi luontomatkailun kasvu luo alueen erämaisuuden säilyttämiselle ja sosiaaliselle kestävyydelle merkittäviä haasteita. Vuosituhannen vaihteessa vallitsevaksi tullut ajatus matkailun edistämisen ja luonnonsuojelun yhdistämisestä sai haastateltavat esittämään myös kriittisiä huomioita. Pitkällä tähtäyksellä, jos kävijämäärät kasvavat entisestään, luonnonsuojelulliset arvot voivat olla vaarassa. Siksi myös vaikutustenarviointiprosesseihin tulisi panostaa entistä enemmän. Yksi UKK-puiston haastateltava kuvasi matkailun vaikutusten arvioinnin ja kestävyyden tulkinnan haasteellisuutta seuraavasti:

- - vaellusretkeilijät pitävät omaa retkeilyään hyvin ekologisena ja Saariselän lähialueen reiteillä liikkuvia päiväretkeilijöitä epäekologisena "massamatkailuna", joka uhkaa luontoa. Tämä ei välttämättä vastaa ekologisen jalanjäljen todellisuutta retkeä, retkipäivää, henkilöä tai alueelle jätettävää matkailueuroa kohti. Puiston keskellä liikkuvan, majoittuvan ja huollettavan retkeilijän ekologinen jalanjälki kulumisena, häiriönä, päästöinä ja hiilijalanjälkenä saattaa todellisuudessa olla selvästi suurempi. Tällaista analyysiä ei tietääkseni ole tehty. (Haastattelu 1)

Kansallispuistoissa tapahtuvaa matkailua ohjaavat kestävän matkailun periaatteet luovat toiminnalliset ja suunnitelmalliset raamit, mutta erilaisten vaikutusten arviointi ja muutosten ennakointi ei ole yksinkertaista (Liu, 2003, s. 461; Saarinen, 2014, s. 9-11; Zeppel 2015, s. 95). Metsähallituksessa käytettävä LAC-malli (Limits of Acceptable Change) tarjoaa työkalun matkailun vaikutusten ja kestävyyden arviointiin (Metsähallitus, 2018a), mutta haastateltavien mukaan mallin käytössä ei ole edetty suunnitellusti. Varsinkin biologisten vaikutusten arviointi on haastavaa ja vaatii resursseja. Kansallispuistoissa käytettävä LAC-malli on väljentynyt vuosien aikana: se sallii aikaisempaa enemmän erilaisia toimintoja puistojen alueella, ja siihen on otettu mukaan paikallisia ja alueellisia variaatioita (Puhakka \& Saarinen, 2013, s. 423). Kansainvälisellä tasolla kestävyyden ja kestämättömyyden määrittelyyn vaadittavien indikaattoreiden määrästä tai laadusta ei ole ollut konsensusta, eikä erilaisten mittausmallien soveltaminen käytäntöön ole ollut lainkaan ongelmatonta (Torres-Delgado \& Saarinen, 2014, s. 42-43).

\section{Kestävä luontomatkailu puistojen yhteistyöyritysten näkökulmasta}

Yrityskyselyyn vastasi siis 21 Kolin alueen ja 4 UKK-puiston alueen yhteistyöyritystä. Vastanneista Kolin yrityksistä enemmistö tarjosi majoitus- ja matkanjärjestäjäpalveluita. Nämä ovatkin tyypillisimpiä toimialoja kansallispuistojen yhteydessä toimivissa yrityksissä. Ravitsemisalan päätoimialakseen ilmoittaneita yrittäjiä oli aineistossa hyvin vähän, mutta moni yritys, jonka päätoimiala on majoitus, tarjoaa myös ravitsemispalveluita. UKK-puiston vastanneet yritykset edustivat matkanjärjestäjä- ja matkaopastoimialaa, majoituspalveluita ja toimialaa "muu". 
Enemmistö kyselyyn vastanneista yrityksistä oli toiminut alueellaan huomattavan pitkään. Kolin yrityksistä miltei puolet (45 \%) oli harjoittanut toimintaansa vähintään 21 vuotta ja kaikki muutkin (55 \%) vähintään 10 vuotta. Myös UKK-puiston neljästä yrityksestä kaksi oli toiminut alueella vähintään 21 vuotta. Vastanneet yritykset olivat siis pääosin vakiintuneita, toimialansa ja toiminta-alueensa hyvin tuntevia - eli kyseessä olivat vahvasti paikallisesti orientoituneet yritykset.

Kyselyn tulokset kertovat, miten puistojen yhteistyökumppanit suhtautuvat kestävyysajatteluun. Asiaa kartoitettiin erilaisten myönteistä tai kriittistä suhtautumista indikoivien väittämien avulla.

Kysyttäessä vastaajien käsityksiä ja kokemuksia kestävyysajattelusta ja sen käytänteistä molempien puistojen yhteistyöyrityksissä eniten kannatusta sai kaikkein kestävyysajattelumyönteisin toteamus: "Ratkaisevan tärkeää ja vielä enempään pitää pyrkiä". Turhana kestävyysajattelua ja sen käytänteitä ei pitänyt yksikään vastaaja. (Kuva 1)

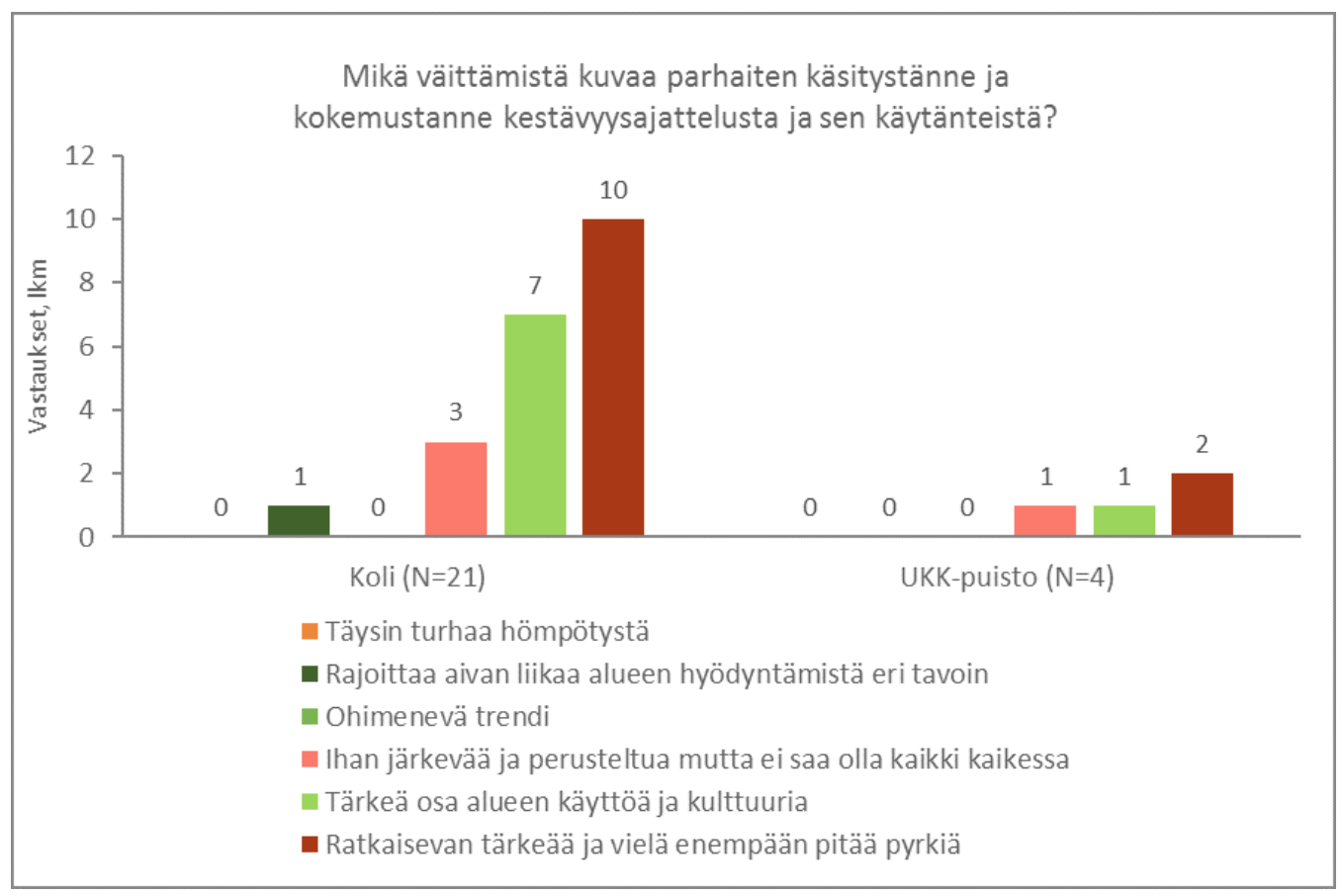

Kuva 1. Yhteistyöyritysten suhtautuminen kestävyysajatteluun Kolin ja Urho Kekkosen kansallispuistoissa vuonna 2018.

Muutamat vastaajat osoittivat jossain määrin kriittistä suhtautumista kestävyysajattelua ja sen käytäntöjä kohtaan: ajateltiin kestävyysajattelun olevan perusteltua, mutta se ei saa olla kaikki kaikessa, tai sen koettiin rajoittavan alueen hyödyntämistä. Kriittisten mielipiteiden olemassaolo on odotettuakin - sen verran suuria ristiriitoja kansallispuistojen kehittämiseen on liittynyt. Myös puistotoimijoiden haastatteluissa tuli esille paikallisten ihmisten kokemus siitä, että 
luonnon- ja maisemansuojelu rajoittaa tai estää matkailun kehittämis- ja rakennushankkeita ja vapaata matkailubisnestä. Kyselyn tulos osoittaa kuitenkin, että 1990-luvun lopulla aloitettu kestävyysajattelun läpivieminen on molemmissa puistoissa kantanut hedelmää ja kestävyysajattelusta on tullut tärkeä osa yritysten toimintaa.

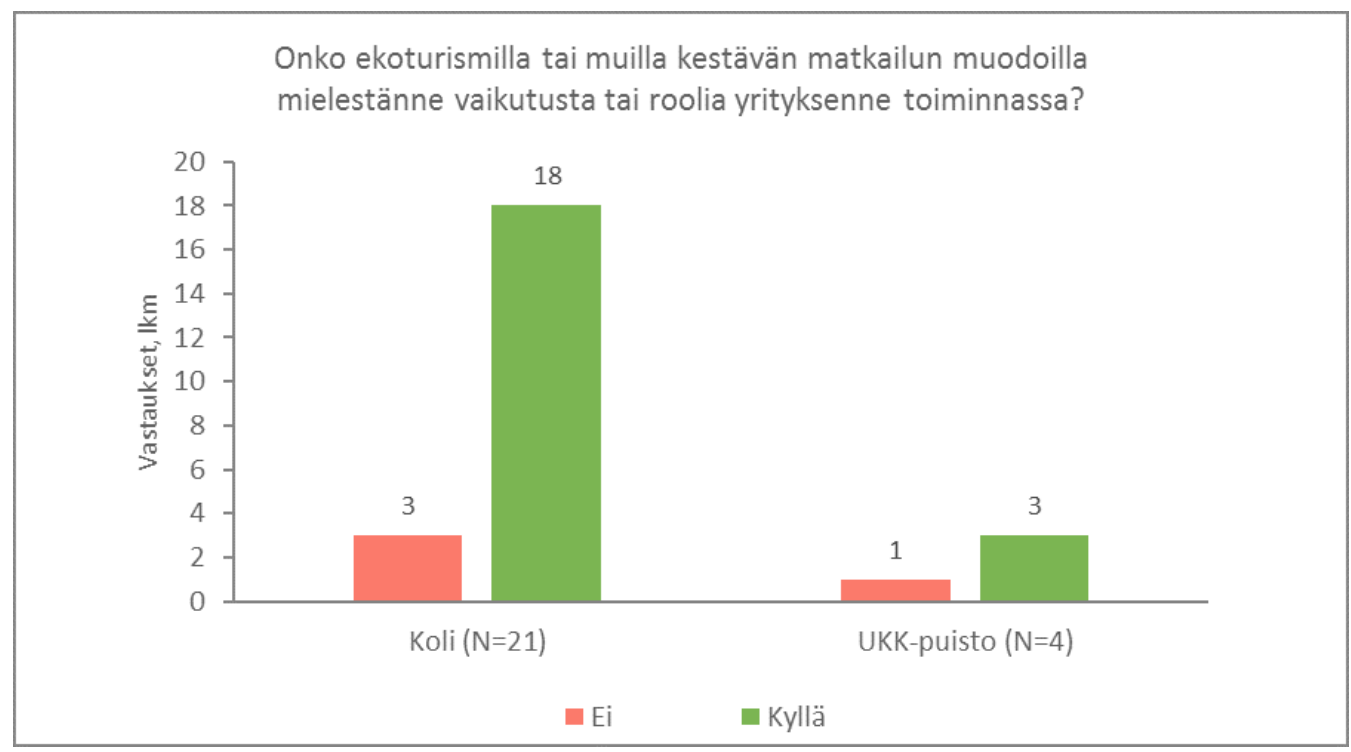

Kuva 2. Kestävän matkailu rooli yhteistyöyritysten toiminnassa Kolin ja Urho Kekkosen kansallispuistoissa vuonna 2018.

Ekoturismin tai muiden kestävän matkailun muotojen merkitystä yritysten toiminnassa nyt tai tulevaisuudessa pidettiin merkittävänä. Molemmissa puistoissa kaikki vastanneet yritykset pitivät ekoturismia ainakin jossain määrin merkityksellisenä tulevaisuuden kannalta ja selvä enemmistö arvioi, että vastaushetkellä eli syksyllä 2018 ekoturismilla tai muilla kestävän matkailun muodoilla on oma roolinsa yrityksen toiminnassa (kuva 2). Vastauksia perusteltiin muun muassa seuraavasti:

Mikäli luonto tuhotaan lakkaa myös matkailu alueelle.(Matkailuyrittäjä, UKK-puisto)

Ihmiset haluavat matkustaa vastuullisesti ja oppia kestävää luonnosta nauttimista. (Matkanjärjestäjä- ja matkaopasyrittäjä, Koli)

Koko toimintamme perustuu kestäviin arvoihin ja toimiin. Olemme tietoisesti valinneet toimintaympäristöksemme kansallispuiston. (Matkanjärjestäjä- ja matkaopasyrittäjä, Koli)

Koko toimintamme perustuu kestävän matkailun arvoihin; tarjoamme kasvispainotteisen aamiaisen, pesemme pyykit ja tiskit ekopesuaineilla, lajittelemme kaikki jätteet ja meillä on oma komposti, jota käytämme puutarhan lannoitukseen, asiakkaiden käytössä on ulkohuussit ja suihkun sijaan peseytyminen on pihasaunalla. (Majoituspalveluyrittäjä, Koli)

Sekä Kolilla että UKK-puistossa oli yksittäisiä yrityksiä, jotka kokivat kestävyysajattelusta ja Metsähallituksen kestävän luontomatkailun periaatteista olevan jotakin haittaa toiminnal- 
leen. Haitat liittyivät ennen kaikkea kansallispuiston alueella tai sen välittömässä läheisyydessä tapahtuvan toiminnan rajoittamiseen. Toimintaa voi olla vaikea kehittää ja kasvattaa, jos uusien rakennusten rakentaminen pihapiiriin tai matkailua edistävien hyvienkin muutosten toteuttaminen on hidasta ja vaivalloista. Kansallispuiston aluetta koskevat rajoitukset eivät ole miellyttäneet kaikkia matkailuyrittäjiä. Esimerkiksi moottorikelkka- ja mönkijäsafarit eivät ole ongelmattomia herkälle ympäristölle. Rajoituksiin liittyvät ristiriidat korostuivat UKK-puiston kyselyssä ja haastatteluissa.

Yrityksiltä tiedusteltiin, kuinka hyvin niissä tunnetaan kestävän luontomatkailun periaatteet. Molemmissa kansallispuistoissa periaatteiden tunnettuus oli yritysten omien näkemysten mukaan hyvällä tasolla, mutta vastaajien joukossa oli muutamia sellaisia, jotka eivät kokeneet tuntevansa periaatteita juuri lainkaan. Kolilla aikaisemmin tehdyissä yritystutkimuksissa on tullut esille ristiriitoja kestävän luontomatkailun periaatteiden tuntemuksessa ja siinä, millä tavoin periaatteet on ymmärretty (Laukkanen, 2010, s. 34; Manner, 2007, s. 156; Sorsa, 2003, s. 60-61). Ylhäältä päin annetut toiminta- ja ajatusmallit voivat käytännössä sekoittua ihmisten omiin käsityksiin kestävyydestä. On myös mahdollista, että kestävän luontomatkailun periaatteet on joissakin tapauksissa omaksuttu vain osittain tai niitä sovelletaan laveasti.

Viimeisimmän Kolilla tehdyn (vuonna 2019 julkaistavan) yritystutkimuksen alustavien tulosten mukaan suurin osa yrittäjistä pitää kestävän matkailun periaatteita hyväksyttävinä ja näyttäisi siltä, että yritysten mielestä niin yritykset itse kuin Metsähallitus ovat onnistuneet toiminnassaan toteuttamaan hyvin kestävän matkailun periaatteita. Haastatellun Metsähallituksen tutkijan mukaan ${ }^{2}$ moni yrittäjä koki kestävän matkailun periaatteiden toteutumisen arvioinnin hankalaksi; erityisen vaikea oli arvioida, miten muut toimijat ovat periaatteita toteuttaneet. Kaiken kaikkiaan tässä artikkelissa tarkasteltavan tutkimuksen ja Metsähallituksen toteuttamien yritystutkimusten tulokset osoittavat, että kestävyysajattelun käyttöönotossa on edetty, mutta toiminnan vaikuttavuuden arviointi on edelleen kesken. Tämä havainto on huomioitava tärkeänä kehityskohteena kestävien toimintamallien luomisessa, ja se nivoutuu kestävän matkailun yleiseen problematiikkaan (Saarinen, 2014, s. 4-7; Sharpley, 2009, s. 77-78).

\section{Hyödyntämättömät mahdollisuudet}

Kolin kansallispuiston yhteistyöyritykset korostivat vahvasti kulttuurihistoriaa alueen hyödyntämättömänä mahdollisuutena. Kulttuurihistoria nähdäänkin tärkeäksi osaksi suojelualueita, eikä kestävän luontomatkailun konseptissa voida puhtaasti erottaa luonto- ja kulttuurielementtejä toisistaan. Tämä näkyi selvästi Kolin kyselyaineistossa. Kulttuurihistoria on kansainvälisesti ajateltuna yksi merkittävimmistä matkailun vetovoimatekijöistä (Dallen, 2018, s. 177-178).

Kyselyyn vastanneiden yrittäjien mukaan Kolin alueen historia on teema, jota voisi tuotteistaa enemmän. Yksi konkreettinen ehdotus oli erilaisten historiateemaisten hevoselämysten tarjoaminen. Tuote voisi olla esimerkiksi vanhojen työhevostaitojen kokeilua ja opettelua sekä metsätöiden tekemistä hevosten kanssa. Kulttuurihistoria ja eläinten kanssa toimiminen sidottaisiin tuotteelliseksi kokonaisuudeksi.

2 Satu Naumasen tiedonanto 14.2.2019. 
Yrittäjien näkemyksiä kulttuurihistorian potentiaalista tukevat Kolin puistotoimijoiden haastattelut. Kulttuurihistoriaa onkin Kolilla jo hyödynnetty laajasti: Kolin ahot ja pihapiirit koetaan tärkeiksi vetovoimatekijöiksi ja niitä on hyödynnetty näyttelyissä, polkureitistössä ja opasteissa. Kulttuuriympäristöä hoidetaan ja pidetään yllä sekä ekologisista että matkailullisista syistä. Tiedollista materiaalia ja paikallista sosiaalista pääomaa on kuitenkin vielä hyödyntämättä.

UKK-puistossa saamelaisten kulttuurihistoriaa on hyödynnetty vaihtelevasti ja saamelaisten osallistuminen on ollut mahdollisuudet huomioon ottaen vähäistä. Haastateltujen puistotoimijoiden mukaan UKK-puistossa ja sen lähialueilla olisi runsaasti saamelaiskulttuuriin ja muuhun kulttuurihistoriaan liittyviä mahdollisuuksia tuotteistamiseen ja lisäkehittämiseen. Saamelaiset eivät kuitenkaan aina suhtaudu myönteisesti matkailutyöhön, vaan se on saatettu kokea alentavaksi.

Kolin kyselyvastauksissa tuotiin esille, että kestävän luontomatkailun kehittäminen on alueella edelleen alkutekijöissään. Yksi lähes kokonaan hyödyntämätön mahdollisuus on Pielinen. Laajan Pielisjärven vajaakäyttö luontomatkailussa todettiin myös Kolin tulevaisuutta käsitelleessä Koli Treffit -tilaisuudessa joulukuussa 2017. UKK-puiston alueella yrittäjät näkivät huomattavia hyödyntämättömiä mahdollisuuksia polku- ja reittiverkostojen kehittämisessä. Etenkin moottoroidusti liikkuville toivottiin uusia reittejä ja toisaalta jalan liikkuville helppokulkuisia polkuja keskeisille näköalapaikoille.

Kansainvälisen tutkimuksen havainto siitä, että kansallispuistoista on tullut yhä enemmän muutakin kuin luonnonreservaatteja (Frost \& Hall, 2009, s. 300-301; Puhakka \& Saarinen, 2013) näkyy hyvin selvästi molempien puistojen aineistoissa. Useimmat kyselyyn vastanneet yritykset kokivat suojelualueen ja kestävyysajattelun taloudelliseksi mahdollisuudeksi. Puistoja ei nähty vain luonnonsuojelualueina vaan aktiivisen toiminnan ja yrittämisen alustoina. Toimiva yhteistyö on elintärkeää yrityksille ja matkailuun liittyvien mahdollisuuksien hyödyntämiselle. Yrittäjät tarvitsevat niin paikallishallinnon kuin Metsähallituksen luomia toimintaedellytyksiä. (Selby, Petäjistö \& Huhtala 2011, s. 453.)

\section{Johtopäätökset}

Tässä luvussa esitetään tutkimuksen johtopäätökset. Keskustelu aikaisemman tutkimuksen kanssa on käyty historiantutkimuksen tapaan edellä tulosten tarkastelun yhteydessä.

Kestävän luontomatkailun uhat ja mahdollisuudet Kolin ja Urho Kekkosen kansallispuistoissa ovat paikallistason esimerkkejä asioista, jotka ovat tulleet esiin luontomatkailun kasvuun liittyvässä kansainvälisessä keskustelussa. Molemmissa puistoissa nousivat esille samat keskeiset teemat: paikallinen yhteistyö, kestävyysajattelun edistyminen ja käyttöönotto matkailupalveluissa sekä toisaalta kestävyyden kokonaisvaltaisen arvioinnin haasteellisuus. Kuvaavaa on, että paikallistason toimijat näkevät haasteet paikallisesta näkökulmasta. Yleisemmän tason haasteet, kuten lentomatkailun kestävyys, eivät nousseet tutkimusaineistoissa esille. Tämä kuvastaa aiheen ongelmallisuutta. Matkailun kestävyys yleisemmällä tasolla ei siirry paikallis- 
tason ajatteluun, vaan kestävyys nähdään ennen kaikkea paikallisena ja paikallisesti ratkaistavana asiana.

Toimiva yhteistyö on todettu ehdottoman tärkeäksi edellytykseksi matkailun ja kansallispuistojen toiminnan kehittämiselle ja sosiaalisen kestävyyden saavuttamiselle, koska sekä Kolin että UKK-puiston kehittäminen on ollut alusta asti kompromissien hakemista eri käyttäjäryhmien ja intressitahojen välillä. Yhteistyön avulla ongelmia on saatu ratkottua. Kestävä luontomatkailu on toiminut käsitteellisenä ja toiminnallisena työkaluna yhteistyön rakentamisessa ja puistojen hyväksyttävyyden lisäämisessä. Matkailijamäärien kasvun myötä lisääntyneet taloudelliset tuotot ovat 2000-luvulla lisänneet myötämielisyyttä luonnonsuojeluun ja kansallispuistoihin.

Sekä Kolilla että UKK-puistossa toimivat yhteistyöyritykset näkevät kestävän matkailun tärkeänä osana toimintaansa nyt ja tulevaisuudessa. Kestävyysajattelusta on tullut olennainen osa puistoalueilla toteutettavaa matkailua ja osa usean yrityksen toimintaideaa. Tämä voidaan nähdä suurena mahdollisuutena kestävän luontomatkailun tulevaisuutta ajatellen.

Paikallisten yrittäjien näkökulmasta kestävän matkailun keskeisimmät hyödyntämättömät mahdollisuudet liittyvät Kolilla kulttuurihistorian tuotteistamiseen. UKK-puistossa olisi mahdollisuuksia etenkin saamelaiskulttuuriin liittyvien matkailutuotteiden kehittämiseen. Yrittäjillä on halua ja ideoita kestävien ratkaisujen löytämiseksi, ja jo nykyisin kulttuurihistorialliset teemat ovat vahvasti esillä molemmissa kansallispuistoissa. Luonnon ja kulttuurin yhdistelmä koetaan omaleimaiseksi ja matkailun kannalta kiinnostavaksi teemaksi.

Metsähallituksen määrittelemän kestävyysajattelun ja käytänteiden omaksuminen ei ole kuitenkaan ongelmatonta. Ylhäältä päin annetut toimintaohjeet sekoittuvat paikallistasolla yksilöllisiksi sovelluksiksi, ja toiminnan vaikuttavuuden arvioinnissa on ongelmia. Luontomatkailun vaikutusten arviointiin käytettävien menetelmien keskeneräisyys ja kokonaisvaltaisen arvioinnin puutteellisuus hämärtävät käsitystä siitä, miten kestävän luontomatkailun tavoitteissa on onnistuttu.

Kolilla tulevaisuuden haasteita luo ympäristön paine matkailupalveluiden kasvattamiseen ja infrastruktuurin rakentamiseen. Alueella nähdään olevan valtavasti matkailullista potentiaalia, mutta kestävyysajattelun painotukset vaihtelevat. Paikallistason toimijat eivät ole homogeeninen ryhmä, vaan suhtautuminen luonnonsuojeluun, turismiin ja kehittämistoimiin voi olla hyvin erilaista. Tämä asettaa haasteita kestävyyden eri osa-alueiden arvioimiselle. Kenen ääntä kuullaan ja mitä osa-aluetta painotetaan? UKK-puistossa monet matkailun kestävyyshaasteet liittyvät puiston ristiriitaiseen identiteettiin: kuinka säilyttää kohteen erämaisuus kasvavien kävijämäärien paineessa? Kansallispuistoille asetetut aluetaloudelliset tavoitteet ja kestävän luontomatkailun periaatteet ovat yhdenmukaiset vain osittain. Taloudellinen kestävyys, sosiaalinen kestävyys ja ekologinen kestävyys eivät aina ole sovitettavissa toimivaksi kokonaisuudeksi. Niin Kolin kuin Urho Kekkosen kansallispuistossa joudutaankin arvioimaan yhä tarkemmin, mihin suuntaan puistojen toimintaa kehitetään ja mitä kestävyyden osa-alueita painotetaan. 


\section{Lähteet}

\section{Kirjallisuus}

Ala-Fossi, K. \& Mikkola, M. (2017). Pyhä-Häkin kansallispuiston kävijätutkimus 2016. (Metsähallituksen luonnonsuojelujulkaisuja, B 225.) Vantaa.

Balmford, A., Beresford, J., Green, J., Naidoo, R., Walpole, M. \& Manica, A. (2009). A global perspective on trends in natural-based tourism. PLoS Biol 7(6). https://doi.org/10.1371/journal. pbio.1000144

Blamey, R. K. (2001). Principles of ecotourism. Teoksessa D. B. Weaver (toim.), Encyclopedia of ecotourism (s. 5-22). Wallingford: CABI.

Borg, P. (2013). Koilliskaira: Erämaan ä̈̈ni, vapauden kaipuu. Suomen ympäristösuunnittelu.

Buckley, R. (toim.) (2004). Environmental impacts of ecotourism. Wallingford: CABI.

Buckley, R. (2012). Sustainable tourism: Research and reality. Annals of Tourism research, 39, 528546. https://doi.org/10.1016/j.annals.2012.02.003

Dallen, J. T. (2018). Making sense of heritage tourism: Research trends in a maturing field of study. Tourism Management Perspectives, 25, 177-180. https://doi.org/10.1016/j.tmp.2017.11.018

Das, D. \& Hussain, I. (2016). Does ecotourism affect economic welfare? Evidence from Kaziranga National Park, India. Journal of Ecotourism, 15, 241-260. https://doi.org/ 10.1080/14724049.2016.1192180

Edgell, D. \& Swanson, J. R. (2013). Tourism, policy and planning: Yesterday, today and tomorrow. New York: Routledge.

Fennell, D. A. (2004). Ecotourism: An introduction. London: Routledge.

Fennell, D. A. \& Dowling, R. K. (toim.) (2003). Ecotourism policy and planning. Wallingford: CABI.

Fletcher, R. (2014). Romancing the wild: Cultural dimensions of ecotourism. Durham: Duke University Press.

Fredman, P. \& Tyrväinen, L. (toim.) (2011). Frontiers in nature-based tourism: Lessons from Finland, Iceland, Norway and Sweden. New York: Routledge.

Frost, W. \& Hall, M. C. (toim.) (2009). Tourism and national parks: International perspectives on development, histories and change. New York: Routledge.

Heinonen, M. (toim.) (2007). Puistojen tila Suomessa: Suomen suojelualueet ja niiden hoito 2000-2005. Helsinki: Metsähallitus.

Keiter, R. (2013). To conserve unimpaired: The evolution of the national park idea. Washington: Island Press.

Kolin kehittämisen iso kuva. Haettu 18.2.2019 osoitteesta http://webdynasty.pohjoiskarjala.net/Dynasty/Juuka/kokous/20182194-8-2.PDF 
Kortelainen, J. (1995). Kolin ympäristöristiriidat ja matkailu: kamppailua ympäristön merkityksestä. Teoksessa J. Järviluoma, J. Saarinen \& A. Vasama (toim.). "Jos metsään haluat mennä...": Näkökulmia luonnon virkistys- ja matkailukäyttöön (s. 63-72). (Metsäntutkimuslaitoksen tiedonantoja 571.) Rovaniemi.

Koskeli-Rantamaa, A. (2016). Kolin kansallispuiston kävijätutkimus 2014. (Metsähallituksen luonnonsuojelujulkaisuja, B 216.) Vantaa.

Kuusisto, K. (2018). Urho Kekkosen kansallispuiston kävijätutkimus 2017. (Metsähallituksen luonnonsuojelujulkaisuja, B 242.) Vantaa.

Laukkanen, M. (2010). Kolin kansallispuiston yritystutkimus 2009-2010. (Metsähallituksen luonnonsuojelujulkaisuja, B 147.) Vantaa.

Lehtinen, A. \& Kiiskinen, K. (18.1.2019). Kolin kehittäminen tuotava tälle vuosisadalle. Karjalainen, s. B4.

Liu, Z. (2003). Sustainable tourism development: A critique. Journal of Sustainable Tourism, 11, 459-475. https://doi.org/10.1080/09669580308667216

Lovén, L. (2005). Kolin kansallispuisto 2010: Hoito- ja käyttösuunnitelma 2003-2010. Metsäntutkimuslaitos. Tutkimusmetsäpalvelut ja Joensuun tutkimuskeskus.

Lähteenmäki. M. (2016). Footprints in the snow: A long history of Arctic Finland. Helsinki: Prime Minister's Office.

Manner, H. (2007). Euroopan kansallispuistoliiton kestävän matkailun kehittämisprosessi ja sen soveltaminen Kolilla. Teoksessa L. Tyrväinen \& S. Tuulentie (toim.), Luontomatkailu, metsätja hyvinvointi (s. 153-160). (Metlan työraportteja 52.) Rovaniemi: Metsäntutkimuslaitos.

Mansikkaviita, R. (2012). Salamajärven kansallispuiston kävijätutkimus 2011. (Metsähallituksen luonnonsuojelujulkaisuja, B 163.) Vantaa.

Martikainen, I. (2016). Kolin luonnonsuojelun vaiheita. Teoksessa J. Partanen (toim.), Elämää kansallismaisemassa: Koli kautta aikojen (s. 372-378). Saarijärvi: Kolin kotiseutuyhdistys.

Mayer, M. (2014). Can nature-based tourism benefits compensate for the costs of national parks? A study of the Bavarian Forest National Park, Germany. Journal of Sustainable Tourism, 22, 561-583. https://doi.org/10.1080/09669582.2013.871020

McCool, S. F. (2009). Constructing partnerships for protected area tourism planning in an era of change and messiness. Journal of Sustainable Tourism, 17, 133-148. https://doi. org/10.1080/09669580802495733

Metsähallitus (2001). Urho Kekkosen kansallispuiston hoito- ja käyttösuunnitelma. (Metsähallituksen luonnonsuojelujulkaisuja, B 60.) Vantaa.

Metsähallitus (2016). Luontomatkailuyritysten toiminta suojelualueilla. Haettu 18.2.2019 osoitteesta http://www.metsa.fi/luontomatkailuyrityksetsuojelualueilla

Metsähallitus (2017). Kansallispuistojen suosio kasvanut koko 2000-luvun. Metsähallituksen tiedote 15.6.2017. Haettu 18.2.2019 osoitteesta http://www.metsa.fi/-/kansallispuistojen-suosio-kasvanut-koko-2000-luvun 
Metsähallitus (2018a). Kestävä matkailu suojelualueilla: Opas matkailuyritykselle.

Metsähallitus (2018b). Kestävän matkailun periaatteet. Haettu 18.2.2019 osoitteesta http://www. metsa.fi/kestava-luontomatkailu

Metsähallitus (2019). Kansallispuistojen käyntimäärät. Haettu 18.2.2019 osoitteesta http://www. metsa.fi/kayntimaarat

Mose, I. (2007). Foreword. Teoksessa I. Mose (toim.), Protected areas and regional development in Europe: Towards a new model for 21st century. New York: Routledge.

Partanen, S. J. (1992). Saariselkä: Magneettimäestä matkailukaupungiksi. Helsinki: Suomen matkailuliitto.

Plummer, R. \& Fennell, D. A. (2009). Managing protected areas for sustainable tourism: Prospects for adaptive co-management. Journal of Sustainable Tourism, 17, 149-168. https://doi. org/10.1080/09669580802359301

Pohjois-Karjalan biosfäärialue. Haettu 18.2.2019 osoitteesta http:/www.kareliabiosphere.fi/

Puhakka, R. (2007). Kansallispuistot murroksessa: Tutkimus luonnonsuojelun ja matkailun tavoitteiden kohtaamisesta. (Joensuun yliopisto, Yhteiskuntatieteellisiä julkaisuja, no. 81.)

Puhakka, R. \& Saarinen, J. (2013). New role of tourism in national park planning in Finland. Journal of Environment \& Development, 22, 411-434. https://doi.org/10.1177/1070496513502966

Puhakka, R., Sarkki, S., Cottrell, S. P. \& Siikamäki, P. (2009). Local discourses and international initiatives: Sociocultural sustainability of tourism in Oulanka National Park, Finland. Journal of Sustainable Tourism, 17, 529-549. https://doi.org/10.1080/09669580802713457

Saarelainen, A. (2016). Matkailun saralta. Teoksessa J. Partanen (toim.), Elämää kansallismaisemassa: Koli kautta aikojen (s. 323-365). Saarijärvi: Kolin kotiseutuyhdistys.

Saarinen, J. (2014). Critical sustainability: Setting the limits to growth and responsibility in tourism. Sustainability, 6, 1-17. https://doi.org/10.3390/su6010001

Saarinen, J. (2018). Beyond growth thinking: The need to revisit sustainable development in tourism. Tourism Geographies, 20, 337-340. https://doi.org/10.1080/14616688.2018.1434817

Selby, A., Petäjistö, L. \& Huhtala, M. (2011). The realisation of tourism business opportunities adjacent to three national parks in southern Finland: Entrepreneurs and local decision-makers matter. Forest Policy and Economics, 13, 446-455. https://doi.org/10.1016/j.forpol.2011.04.002

Sharpley, R. (2009). Tourism development and the environment: Beyond sustainability? London: Sterling.

Sorsa, R. (2003). Matkailun suhde ympäristöön: Kolin alueen yritykset kestävän matkailun toimeenpanijoina. (Metsäntutkimuslaitoksen tiedonantoja 883.) Rovaniemi.

Sustainable development of tourism. Haettu 18.2.2019 osoitteesta http://sdt.unwto.org/content/ about-us-5

Swarbrooke, J. (1999). Sustainable tourism management. Wallingford: CABI.

Torres-Delgado, A. \& Saarinen, J. (2014). Using indicators to assess sustainable tourism development: A review. Tourism Geographies, 16, 31-47. https://doi.org/10.1080/14616688.2013.867530 
Tuomi, J. \& Sarajärvi, A., (2002). Laadullinen tutkimus ja sisällönanalyysi. Jyväskylä: Gummerus.

Utting, P. (2015) (toim.). Revisiting sustainable development. Geneva: UNRISD.

Virolainen, A. (6.1.2019). Kolille halutaan autoille lisää pysäköintitilaa. Karjalainen, s. A24.

Ympäristöministeriö (2002). Ohjelma luonnon virkistyskäytön ja luontomatkailun kehittämiseksi. Helsinki.

Zeppel, H. (2015). Environmental indicators and benchmarking for sustainable tourism development. Teoksessa S. Gössling, M. C. Hall \& D. Scott D. (toim.), The Routledge handbook of tourism and sustainability (s. 187-199). New York: Routledge.

\section{Haastatteluaineisto}

Haastattelu 1: Sähköpostihaastattelut 7.12.2017, 8.12.2017 \& 18.12.2017.

Haastattelu 2: Sähköpostihaastattelut 13.12.2017 x 2.

Haastattelu 3: Sähköpostihaastattelu 1.9.20107 \& puhelinhaastattelu 14.9.2017.

Haastattelu 4: Puhelinhaastattelu 1.12.2017 \& sähköpostihaastattelu 7.2.2018.

Haastattelu 5: Sähköpostihaastattelut 8.9.2017 \& 12.9.2017.

Haastattelu 6: Sähköpostihaastattelu 4.1.2018.

Haastattelu 7: Sähköpostihaastattelu 20.12.2017.

Haastattelu 8: Haastattelu Kolilla 27.6.2017 \& sähköpostihaastattelu 8.1.2018.

Haastattelu 9: Haastattelu Itä-Suomen yliopistolla Joensuussa 8.11.2017.

Haastattelu 10: Haastattelu Luonnonvarakeskuksella Joensuussa 18.1.2018.

Haastattelu 11: Puhelinhaastattelu 14.2.2019.

\section{Kyselyaineistot}

Kolin digitaalinen kyselyaineisto.

UKK-puiston digitaalinen kyselyaineisto.

\section{Havainnointiaineisto}

Koli Treffit 20.12.2017.

Kolin matkailun kehittämistilaisuus 20.1.2018. 